\title{
Extraction Contracting: The Struggle for Control of Indigenous Lands
}

Dayna N. Scott

Osgoode Hall Law School of York University, dscott@osgoode.yorku.ca

Source Publication:

South Atlantic Quarterly (2020) 119 (2): 269-299.

Follow this and additional works at: https://digitalcommons.osgoode.yorku.ca/scholarly_works

Part of the Indian and Aboriginal Law Commons

\section{Repository Citation}

Scott, Dayna N., "Extraction Contracting: The Struggle for Control of Indigenous Lands" (2020). Articles \& Book Chapters. 2808.

https://digitalcommons.osgoode.yorku.ca/scholarly_works/2808

This Article is brought to you for free and open access by the Faculty Scholarship at Osgoode Digital Commons. It has been accepted for inclusion in Articles \& Book Chapters by an authorized administrator of Osgoode Digital Commons. 


\title{
Extraction Contracting: The Struggle for Control of Indigenous Lands
}

\author{
South Atlantic Quarterly, 2019 (pre-publication version) \\ Dayna Nadine Scott
}

What constitutes 'consent' to extraction in the contemporary moment? How do we know when it has been freely given? How does it manifest in the world? Prime Minister Justin Trudeau, when defending his government's support of the controversial Transmountain Pipeline Expansion project over the past year has often included reference to the fact that more than 40 First Nations along the proposed route have signed "Mutual-Benefits Agreements" with the company. In the context of increasingly contested and politicized resource extraction projects, and reinvigorated and revitalized Indigenous legal orders, what should we make of the negotiation of private contractual agreements now routinely offered up as evidence of consent?

In this essay, I consider the dynamics of 'consent by contract' or what others have called 'negotiated justice' (Szablowski 2010; Dezalay 1994) in the extractive sector by thinking through what the specific mechanism of contract accomplishes for the parties, and what governing by contract means for the interests of so-called non-parties. The 'contractual turn' of the past two decades has been documented extensively in many contexts (see for example Affolder 2012; Gaathi and Odumosu-Ayanu 2015; Zumbansen 2018), but here I focus on the rise of agreement-making between companies in the extractive sector and Indigenous communities in Canada. These agreements now come in the form of 'impactbenefit agreements' (IBAs), 'mutual-benefit agreements', and 'relationship-agreements'. Here, I build on the critical scholarship examining these contracts by investigating whether there is any significance to the specific form in which the parties' expectations are expressed. What does it mean to govern extraction through contract?

The primary literature I draw on is contract law scholarship, including writing about contracts by legal scholars going back several decades to the critical legal studies movement, as well as relational contract scholarship, and the more recent writing examining the contractual turn in private transnational governance (see Cutler and Dietz, 2018). I hope to advance understandings of IBAs by applying these insights to a debate that has been dominated by critical geographers and political economists thus far. These interventions have generated crucial questions about representation, power, jurisdiction, and the interpellations between private and public that IBAs bring to the fore. There is also an important body of interdisciplinary scholarship investigating the social, political and economic conditions on the ground producing the context in which the contracts are negotiated, and their consequences, with significant contributions by socio-legal scholar David Szablowski (in the Latin American context) and public administration scholar Ciaran O'Faircheallaigh (in the settler colonies of Australia and Canada). Finally, there have been recent interventions by socio-legal scholars and practitioners examining the interplay between IBAs and settler law in relation to environmental protection, Aboriginal rights and Indigenous law (see for example Graben, Cameron and Morales 2019; Robertson 2019; Kamphuis 2017; OdumosuAyanu 2018; McLean 2019). 
In terms of methodology, my reading of these literatures has been supplemented by a small number of key informant interviews with leading lawyers and consultants with extensive experience negotiating IBAs on behalf of First Nations in Canada. ${ }^{1}$ I also rely on the close reading of a few recent legal cases that have skirted around the margins of the deal-making dynamics, as well as documents disclosed through litigation and obtained through access to information requests in the context of contested extraction approvals affecting Indigenous lands. ${ }^{2}$

Several points are immediately obvious on applying the insights of the contract law scholarship. First, and most basic, is that the form by which the parties' expectations and obligations are expressed determines, at least formally, the remedies that will be available upon breach. Using contracts to govern extraction means that the 'remedies' the parties can count on when things go awry, will be, for the most part, limited to contract remedies as defined by the settler state's common law. It goes without saying that under this regime, 'non-parties' have no remedies. Further, the remedies available upon breach are understood to determine how the parties approach whether they will decide to breach the agreement, or continue to invest in compliance. But in fact, what we observe on the ground is that the formal contract law remedies matter very little to the parties to IBAs, and are almost never invoked. Further, one of the so-called 'nonparties' to these agreements, the settler state, is not only tangentially involved in the negotiations, it basically sets the terms.

Second, the 'contract realists' in the critical legal studies movement observed that employing contract as the form of expressing the parties' expectations has benefits for the parties with the most entrenched wealth. In other words, these scholars would have predicted that companies in the extractive sector stand to gain more from this contractual turn than the contracting Indigenous communities do. This makes sense, since the extractive companies tend to be 'repeat players' and as such become the 'architects' of the agreements in the sense that they set the rules, draft the protypes and shape the precedents, or at least their lawyers do (Affolder 2012). In a contractual regime, where the parties are "free to choose whatever procedural rules and substantive laws they consider most suitable to govern" their relations (Cutler and Dietz, 2019: 4), those rules and laws would be expected to favour the companies. On the other hand, the contracting Indigenous communities may be right to judge that their position under the contractual regime is stronger than it is under the current public law regime provided by settler legislative frameworks and associated jurisprudence.

It would be tempting to argue, then, that the turn to contracts is primarily a mode of risk mitigation employed by both parties to further their own economic interests in a context of pervasive uncertainty or inadequacy in the public law framework. This is indeed how the bulk of the scholarship has approached the interpenetration of the public and private in terms of IBAs - that the contracts are 'filling the gaps' of an inadequate regulatory regime and constitutional jurisprudence (see for example, McLean 2019; Fidler and Hitch, 2009). On this understanding, while the use of contract benefits the companies more, reliance on the agreements can mitigate the risk of large losses for both parties. The companies avoid a highprofile, reputation-harming dispute that lands them in court facing delays, and the communities avoid being saddled with the adverse impacts of a project that they derive no benefits whatsoever from. The contracts allow a hedging of bets, then, whereby the worst-case scenario is avoided for both parties, on a case-by-case basis. The First Nation parties may also be able to secure 'enhanced environmental protection measures' beyond what is required through settler state law (Robertson, 2019), but the 
prospects for Indigenous communities, collectively, to regain meaningful control and jurisdiction over extraction on their territories in the long term are undermined.

I will argue that this conception paints the state into too passive a role, however. Who are the real parties to these contracts? The evidence reviewed here demonstrates clearly that the state is an active participant in shaping the contractual outcomes. The contemporary practices of extraction contracting in fact conceal a multitude of trade-offs that are incurred as interests and values typically considered part of the public law sphere are moved into the private sphere through the deployment of contract (Affolder 2017). In other words, it is not the contractual form itself that entrenches private authority, but the way that state actors are holding space for these relations to do the governing. The contracts are not proliferating as autonomous actors seek to fill a void in the public law regime, so much as the settler law is holding open the gap for the private law mechanisms to fill, because the contractual regime serves a purpose in the settler state's interests.

Specifically, the private contractual regime normalizes and facilitates the state's provision of access to Indigenous lands for extractive capital. Thus, despite the fact that the emergence of IBAs might be considered an artifact of the crisis caused by Indigenous resistance to the settler state's inclination towards accumulation by dispossession to begin with, the significance of the turn to contracts to govern extraction cannot now be understood without coming to view the deals as a part of the larger legal architecture of settler colonial capitalism that they have been absorbed into. With the contracts satisfying the parties - at least to a limited extent in the short term -- there is less pressure on the state to resolve the obvious failure of the public law scheme to ensure that Indigenous peoples' can exercise their territorial governing authority. Consent by contract, then, is a crucial node in the contemporary contest over jurisdiction between the settler state and the surging Indigenous resistance.

In the first part of this paper, I outline the dynamics of 'consent by contract' that produce a market for consent in the contest over control of resource extraction on Indigenous lands, with a focus on Canada, although there are resonances with the dynamics in many other parts of the settler colonial world, if not broader. Consent by contract is a mode of governance that attempts to define the social, political, ecological and economic relations regarding the use of Indigenous lands solely through confidential bargaining and agreement-making between private extraction companies and First Nations, but in fact affords the state a key role in setting the terms. Documents filed in relation to the recent treaty case of Yahey v British Columbia (2018) expose the faulty logic inherent in the assumption that a Band's conclusion of an IBA can be equated with the community's consent to a project.

In the second part, I review briefly some insights from contract law theory, reaching back to critical legal studies theorists of the 1980s and 1990s, to relational contract theorists, and to the contemporary theorists of transnational private governance. Documents disclosed in the recent judicial review decision of Eabametoong First Nation v. Landore (2017) demonstrate the high degree of penetration of state actors implementing public law processes, such as permitting for early exploration, into the negotiations between a First Nation and a junior mining company. Ultimately, it is not only that the settler state law sets the context for what can be negotiated between the parties, it is also that state actors actively facilitate the agreement-making, influence the parameters of the deal, and are invested in the outcomes. Most significantly, the settler state then draws inferences adverse to Indigenous land interests from the very fact of these negotiations. 
Finally, in the third part I argue that the phenomenon of "extraction contracting", even as it masquerades as a mode of private governance, in fact engages crucial public and constitutional governance questions. I conclude that it is not so much that the contracts are filling a gap in the inadequate public regulatory regime and associated jurisprudence (although the inadequacy is real), but that the public law regime is actively holding open the space for extraction contracting to fill because it insulates the settler law from demands for reform. If we take a clear look, based on these insights, we can see that the status quo flows from more-or-less deliberate decisions by state actors to rely on extraction contracting to determine the highly political outcomes to conflicts over land that are in the long-run detrimental to the Indigenous parties (with whom the state is in a fiduciary relationship). Why? I argue that it is to delay the inevitable break-down of the state's jurisdictional authority on those lands, which will entail radical wealth redistribution from capital to Indigenous peoples.

\section{Part I: The (Rigged) 'Market' for Consent}

The dynamics of resource extraction in Canada are largely, and increasingly, shaped by the negotiation of a complex web of contractual agreements. These are not solely IBAs: they also include resource-revenue sharing agreements between tribal councils and provincial governments, as were recently concluded in Ontario, and 'economic benefits agreements' as in British Columbia; early exploration agreements and MOUs between First Nations and mining companies; framework agreements between communities and various governments and agencies over infrastructure or environmental assessment funding, among others. Over the past several years, companies in the extractive sector have come to accept that this 'dealmaking' with Indigenous governments is a necessary part of the game - and in Canada, it is one that is considerably more predictable than attempting to comply with the Supreme Court of Canada's consultation framework established by jurisprudence interpreting s.35 of the Constitution Act, 1982 and hoping for the best. As many examples in this volume demonstrate, approved projects are not being built because of lengthy court proceedings, and even success in courts cannot guarantee that projects will proceed, because of the increasing capacity of Indigenous land defenders to disrupt extractive operations by asserting jurisdiction (see for example, Curran et al, Benton and Cochrane). The public law framework provided by settler law and jurisprudence, we are told, is not capable of achieving the 'resource certainty' that industry demands. Thus, negotiating a deal has become the first priority of companies interested in advancing a controversial extractive project, and - as much as they claim otherwise -- facilitating those deals has become a key task of state actors attempting to "re-legitimize extraction" (McCreary and Turner, 2018). Signed contracts have come to 'stand-in' for expressions of consent in the contemporary moment.

Even though it is very difficult to understand how the mere fact of a signed agreement could on its own constitute evidence of free, prior and informed consent (FPIC) either as it is understood in international law under the UN Declaration on the Rights of Indigenous Peoples ("the Declaration"), or as it is understood in Indigenous legal traditions, we can observe that extraction is de facto authorized by the signing of a contract between industry and affected communities, in Canada as in other settler societies (Papillon and Rodon 2016). That is, political actors in settler governments are putting forward the successful conclusion of deals as crucial legitimation for supporting contested resource projects, and companies are leveraging that 'consent' as a valued asset when marketing their projects to potential investors (Olynyk et al 2018). 
But how is this 'authorization' is granted in law? Extraction is clearly governed on the ground by a range of overlapping and potentially conflicting norms and processes at the intersection of the relevant Indigenous, settler state, and international legal orders. As Pasternak (2017) has demonstrated, Canada is aptly characterized as an uneven patchwork of competing and overlapping claims to jurisdiction. Multiple ways of authorizing extraction include: the settler state's common law - from its contractual regime, to its Aboriginal rights jurisprudence under s. 35, which details a duty to consult and accommodate in respect of Aboriginal and Treaty rights; settler state legislation, such as provincial resource laws governing oil and gas development, mining and land-use planning; international legal norms, such as the FPIC standard in the Declaration; and most fundamentally, extraction is authorized, altered or rejected according to the Indigenous laws applicable to the territory in question (Scott \& Boisselle, 2019). Acknowledging this plurality by drawing attention to contemporary enactments of Indigenous territorial authority challenges and complicates the exercise of presumed-to-be-exclusive state jurisdiction over natural resources (McCreary and Turner, 2018).

The contractual regime, in the form of IBAs, emerged in the 1990s. The agreements have gone, according to one insider, "from being discretionary to being compulsory" over the past decade to the point that it is "unthinkable not to have one" (Webster 2019: at 28, 29). The basic deal is as follows: the Indigenous community receives a "package of measures" that typically includes promises to minimize or monitor environmental impacts and various economic benefits such as annual payments and/or local employment targets (O’Faircheallaigh, 2003:2; Expert Panel, 2017; Sosa \& Keenan, 2001). In exchange, the community provides access to its lands, and offers support for, or acquiescence to, the project. Sometimes the First Nations are also expected to agree to a release of past infringements and future claims (Gilmour and Mellett, 2013; McLean 2019).

Many scholars have raised concerns about the way the deals are struck. These include complex questions of representation, not only about whether members of affected communities are able to fully understand the proposed terms of a deal before having to register a view (Cameron and Levitan, 2014), but also about who has the authority to provide consent on behalf of a community. Typically, the authority to sign an IBA is presumed to lie with the Chief and Council through a Band Council Resolution, but this glosses over the fact that each Indigenous community will have its own political system structured by its unique legal order (Borrows, 2010). Recognizing this fact means acknowledging the potential applicability of multiple avenues for securing the community's consent, including not only resolutions passed by Band Councils established under colonial legislation, but also hereditary processes derived from Indigenous legal orders (Graben, Cameron and Morales, 2019) - generating challenging questions about where authority lies, over which lands, and how community deliberation feeds into its exercise.

There is also widespread concern that confidentiality clauses, which typically prohibit the communication of the contents of the contracts to anyone outside the negotiating process, are inhibiting "crosscommunity comparisons... and holistic discussion of benefits and valuable experiences among communities..." (Caine and Krogman, 2010: 85). O'Faircheallaigh, who has conducted the largest empirical study of the negotiated outcomes from a number of IBAs in Canada and Australia, found that the 'competitive element' - the sense amongst communities that gains made by one First Nation would reduce the resources available for a neighboring First Nation - was exacerbated by the confidentiality provisions. 
Legitimate worries also exist in relation to the "support and cooperation" covenants that seek to prohibit "beneficiary populations" from opposing the company's project in any regulatory proceedings or undertaking actions that could impede or delay the development. The First Nation is commonly expected to agree that it will not object to the issuance of any licenses, permits, authorisations or approvals in any regulatory proceedings. These provisions have been compared to "gag orders" in the sense that they purport to prevent community members from voicing concerns if new impacts come to light only after the development gets off the ground (Cameron and Levitan, 2014). Reported commitments made by First Nation parties range from "non-objection" to "express support", with the IBA usually listing the kinds of 'oppositional activities' that the First Nation is prohibited from undertaking (Bielawski 2003, O’Faircheillaigh 2016). Multiple negotiators I interviewed indicated that some companies seek to bind the First Nations to contractual terms that would require the Chief and Council to take positive steps to publicly defend the project against critiques levelled against it - at least in the context of official regulatory proceedings, if not in the general public domain. As O'Faircheallaigh sees it, the First Nation parties are accepting constraints on their ability to exercise their rights - whether inherent rights, constitutional rights or rights granted though settler state legislation, in exchange for very modest benefits that may have also been possible without the IBA (2016:166).

Finally, there are serious concerns about the equitable distribution of both benefits and potential harms. This is as true within communities as it is between them, with gender being a crucial consideration (Graben, Cameron and Morales, 2019; Fidler and Hitch 2007; Wiebe and Konsmo, 2014). Jobs, training and economic benefits of extraction typically benefit men in the communities, while major extractive projects, through the introduction of "man camps" and the opening up of remote areas with new infrastructure, pose profound risks to Indigenous women and girls (Women's Earth Alliance and NYSHN, 2016). The recently-released Final Inquiry Report into Missing and Murdered Indigenous Women and Girls (2019) in Canada states explicitly that governments must "do a more thorough job of considering the safety of Indigenous women and children when making decisions about resource extraction on or near Indigenous territories" (at 584).

On one view of IBAs, Indigenous communities are exercising jurisdictional autonomy as self-determining nations when they negotiate directly with industry towards goals of economic self-reliance. Critics, on the other hand, say that the agreements, because they are "one-offs", confidential, and have no minimum requirements (Mining Watch Canada, 2011), undermine the practical ability of First Nations to determine desired land uses for themselves and leave them to "self-determine" within the very narrow confines of extractive capitalism (Dempsey, Gould and Sundberg, 2011) and a wage economy. But in the end, it is clear that the opportunity to negotiate a deal represents a chance for a community to "not only gain economically... but also affect the trajectory and scale of development" (Caine and Krogman 2010, 77) an outcome that is hard to otherwise come by through the settler state's public law framework.

And there is the rub: the fundamental problem is that the Indigenous communities whose lands are threatened by extractive projects are not recognized as holding the jurisdiction to decide whether or not permits should be granted in the first place. Strictly considering the current state of doctrine in settler law today, notwithstanding the adoption of the UN Declaration, the idea of FPIC - and conversely, the possibility that 'no' could mean 'no' - is not yet a feature of the public law regime in Canada (Peerla 2012; Hamilton 2019), or other jurisdictions (Szablowski 2010). Whereas the Declaration, according to UN Special Rapporteur James Anaya (2014), is rooted in the affirmation of the right of Indigenous 
peoples, as self-determining peoples, to have control over their lands and their futures, the Canadian state fears that implementing this vision would amount to giving Indigenous peoples a "veto" over resource development (Imai, 2017; Papillon and Rodon 2017). That is because the right of Indigenous consent to development on their traditional lands is seen as threatening to the basic foundational notion of 'permanent sovereignty over natural resources' for states (Szablowski 2010).

The primary jurisprudential tool that settler courts in Canada use to decide these disputes is the duty to consult and accommodate - a spectrum of consultation and accommodation rights developed by the settler courts to manage areas on which Aboriginal and Treaty rights have been claimed or recognized. And under this jurisprudence, even on the end of that spectrum where title or treaty rights provide the most scope for First Nations to consent to or refuse projects, those rights remain subject to the Crown's “justifiable infringement” (Scott \& Boisselle, 2019; Imai, 2017). The situation was summed up well by Chief Allan Adam of Athabascan Chipewyan First Nation, whose community is situated near the Alberta tar sands, in September 2018. Having long been a central critic of the devastating impacts of extractive projects in the territory, he finally signed an IBA with mining giant Teck Resources, stating:

"We've been fighting industry for how long? And we've spent well over \$1-million in court fees with nothing tangible in return... So what am I supposed to do?...I don't want to do this. I didn't want to make this decision but I had no choice. I had to make sure ..our people are going to benefit from it for the future" (McCarthy, 2017).

As Imai says, "[t]he problem with the consult standard is that the community feels powerless because they are powerless. It is difficult for people to trust a process of discussion when they know that no matter what happens, the final decision is not in their hands" (Imai, at 385-386). In other words, negotiations towards IBAs are always "premised on the assumption that the project will be approved" (Papillon and Rodon 2017: 13). It is merely a matter of deciding on the "compensation package [that will be provided] in exchange for consent" (Ibid; see also Weitzner, 2006). We are asked to believe that consent has a price, and that it can be bought and sold in a private market.

Is a signed IBA evidence of a community's consent?

Yahey v British Columbia concerns a larger Treaty rights claim by the Blueberry River First Nation; it is part of the wave of cases now coming forward under the banner of a "meaningful right to harvest" (Imai, 2017). The Band is arguing that the cumulative impact of state permitting processes for industrial uses has transformed the landscape to such as extent that it is undermining the community members' abilities to use their traditional territory for hunting and fishing as guaranteed in Treaty $8 .{ }^{3}$ In this specific ruling, however, the court answers the state request for disclosure of any IBAs that Blueberry River had signed with project proponents. British Columbia argued that the IBAs would demonstrate the Band's consent to the projects, and that the Band had already been compensated for any violation of their Treaty rights. In documents filed in the ongoing litigation, Blueberry River objects, arguing that "since the matter was out of their hands, signing an impact benefits agreement or otherwise participating in industrial development cannot be viewed as acquiescing in the diminution of their treaty rights and thus is not relevant to the Province's defence" (Aelene Guingcango, Affidavit of April 11 2018: 4). In fact, the Band stated, it had formally objected at the approvals stage to two gas transmission projects and only entered into agreements with the companies "after the Province had approved those projects over the plaintiffs' objections" (Merli de Guzman, Affidavit of December 9 2017: 2-3). 
In the case of one of the projects, Blueberry River details how it wrote to the Ministers responsible for the project requesting that they deny the approval, and asking the Crown to engage the Band to discuss threats to their treaty rights, but the request was not responded to. The Band offers the evidence to show that the approval was granted shortly after and almost 11 months passed before the IBA was entered into. The Band argues that these approvals demonstrate that the environmental assessment process is flawed and that the Crown failed to fulfill its duty to consult accommodate the Band's concerns about negative effects on treaty rights and the environment (Ibid. 2-3).

These negotiations occurring as part of the Blueberry River litigation demonstrate explicit state attempts to re-legitimate extractive developments, even when they have been approved over the explicit objections of affected Indigenous peoples. One lawyer I interviewed stated in respect of IBAs like these that, "at best, you are negotiating over minor environmental mitigation measures...on a territory that really cannot bear any more projects". Until communities actually have the power to say 'yes' or 'no' to extractive activities on their ancestral homelands, it is impossible to conclude that an IBA can constitute evidence of meaningful 'consent' to a project. There is a structural power imbalance in place, stemming "from the ability of companies to decide which communities they will negotiate with, to end negotiations, and more generally to get projects approved and proceed without IBAs" (St-Laurent and Le Billion at 8).

\section{Contract as Risk Management}

From this we could conclude that an IBA is simply extra insurance for companies - "IBAs have proven to be a useful tool for industrial proponents to manage risk", according to three corporate lawyers writing recently in Lexpert magazine (Olynyk, Bergner and Shipley, 2018/2019). Hania (2019) states that an IBA is a "mechanism that stabilizes the risk inherent in [an extractive] project" (539). Similarly, a negotiator that I interviewed agreed that "political risk is a major motivator" for companies in terms of bringing them to the table. ${ }^{4}$ And risk management is an aim of communities as well. Because settler law does not put First Nations in a position to envision their own projects for the territory, IBAs are often perceived as the "best (and often last) option for influencing the flow of resources back to the community" (Caine and Krogman at 85), meaning that other parties' development priorities are inevitably thrust on First Nations to consider. But communities do have their own priorities, often with built-in notions of environmental sustainability, intergenerational justice and visions for land-based economies and livelihoods not compatible with a wage economy (Simpson, 2016).

Unfortunately, as the literature shows however, IBAs cannot be relied on for generating "future benefit streams" (Caine and Krogman 2010:78; O'Faircheallaigh 2016) nor for enacting alternative visions of sustainable economic development (Cameron and Levitan, 2014). This failure derives, at least in part, from the fact that IBAs make First Nations more dependent on revenues generated through extractivism in order to meet community members' basic fiscal needs. Extractivism is a mode of accumulation that is non-reciprocal and oriented to the short-term, generating profits for distant owners and very little in the way of benefits for local people (Veltmeyer, 2013; Acuña, 2015). This creates a situation where communities who have signed IBAs, once all the resources are extracted, are left with no trace of the promised wealth and prosperity, but with the lasting legacy of a comprised homeland. As political ecologists have demonstrated, even new forms of 'progressive extractivism' that incorporate benefit sharing with Indigenous communities - a function of the contractual turn -- tend to push communities towards standard forms of economic development and a wage economy (Gudynas, 2009). This is because 
they depend on growth, an ongoing and linear process of material 'progress', forcing communities to accept a re-definition of relations with land into capitalist terms of revenues, assets and individual gain (Ibid; Veltmeyer and Bowles 2014).

To conclude this part, I argue that we cannot simply see the turn to contracts as an expression of autonomy or self-determination without investigating the background context for the negotiations, including the underlying power relations. And here it is clear that the backdrop set by the settler jurisprudence takes all of the leverage away from the First Nations. As Szablowski (2010) says, the formal regulatory regime forms the 'skeleton' that supports and structures the engagement process, providing valuable resources and bargaining entitlements to the parties. In this way, the settler law's allocation of legal rights and duties comes to shape the private ordering. The most crucial of these allocations is that the Crown claims underlying title to, and jurisdiction over, all of the lands within the settler state's borders.

Contracts clearly include and embed not only private law norms, but state law norms as well. The parties are "bargaining in the shadow" of the public law. As Wai (2008) says, while contractual relations are assumed to be private consensual relations, state law is always ordering the interactions of the parties. But, it is not only that private agreements incorporate and embed regulatory standards and assumptions derived from public law, as I have shown in this part, but that those agreements implicate a broad range of public interests and interests of so-called 'non-parties', and that the state is actively engaged in shaping the contractual outcomes, as I will demonstrate next.

\section{Part II: Relational Contracts, and their Remedies}

"[M]uch of contract theory depends on a picture of consensual, uncoerced transactions"

(Macauley 2015: 110).

American legal scholar Stewart Macauley spent a career breaking down the formal assumptions of contract doctrine to demonstrate how the real-world conditions of contracting differed sharply from the assumptions in the jurisprudence. Amongst the assumptions he drew into question: that parties carefully draft contracts on equal terms, which they fully understand and agree to (2003). More often, Macauley argued, the written contract is incongruent with the actual expectations of the parties. As Treaty people, we should by now be familiar with this idea. One of the key reasons for the disparity, according to Macauley, is that those who negotiate the deal are not the ones who draft it, and not the ones who have to perform it. But as he demonstrates, "proving what the real deal was can be very costly...[as] experts are not free" (44) (also an apt remark in the context of both IBAs and Treaty).

Macauley was writing alongside Ian Macneil, another American legal scholar whose work launched the field of "relational contract theory" with the observation that how parties behave in their contractual relations is less about the contract terms and more about how they hope and expect to relate to each other in the future. This scholarship takes for granted that there are many factors operating outside of the "four corners of the contract" that shape the relations between the parties, and the decisions they make in relation to its breach (Macauley 2015). 
In fact, a point made in early contract law scholarship is that the remedies available for breach of contract essentially determine the "risk-sharing" as between the parties (Polinski, 1981). The remedy available against a breaching party will influence a party's decision as to whether they will breach, or invest in compliance. In fact, the purpose of providing "sanctions" for promises broken, according to the classical liberal contract law theory Macneil critiqued, is to protect the reliance on promises and to prevent unjust enrichment (Macneil 1962). Unjust enrichment, or the law of restitution, is based on the 'moral principle' that the status quo should be restored between the parties where one's loss has unjustifiably become the other's gain (Burrows, 2011).

What is "unjust enrichment" in the context of extraction contracting? The company would be unjustly enriched, according to contract law doctrine, if the company receives the social license, permits, or the "acquiescence" of the community, but the First Nation does not receive the promised benefits. And the reverse: the First Nation would be unjustly enriched if it received benefits under the agreement (payments, as an example) but withheld or withdrew its support or took other measures to undermine the company's social license, asset value etc. The order in which the parties deliver their "goods", then, clearly matters in the real world of extraction contracting. In the context of most IBA negotiations, the company benefits first and performs later, ie. the First Nation agrees to acquiesce or stay silent through regulatory proceedings (if not stand on a stage and shake hands in front of cameras), and the cheques begin rolling in later. On the flip side, the First Nation performs/delivers first and benefits later. In fact, cheques for annual payments are easily interrupted, but regulatory approvals tend to be much more difficult to reverse or rescind. So, the stock response that lawyers give when asked about a community's remedies under IBAs in the case of a company's breach of obligations - that a community can always withdraw its support -- seems out of touch with the reality of when and how leverage can be used on the ground. Several of the negotiators I interviewed agreed that the First Nation's points of leverage depend heavily on the timing of the regulatory approvals. In fact, one negotiator acknowledged that a reason why the 'expressions of support' provisions of an IBA are typically considered more 'enforceable' than most, is that those expressions are expected prior in time to the performance of the companies obligations.

Knowing something about contract remedies - the recourse that is available to each party under the law in the case of breach - and how they can access it, then, is part of understanding the implications of the turn to contract to govern these relationships. The most important thing to know is that the general rule is money damages. "Contract law is generally understood to require no more of a person who breaches a contract than to give the injured party the "benefit of the bargain"" (Thel and Siegelman 1181). As long as the company can compensate for the breach (in monetary terms), it is, according to the settler law of contract, free to break its promises. This rule has obvious deficiencies for the Indigenous parties for whom many of the values sought to be protected through the IBA, such as a sacred river system, ecological integrity, or culturally significant sites, are not compensable with money damages.

The other general rule is that the parties may determine and set out in the agreement how they wish to handle disputes. Typically, this includes mediation provisions, and where mediation fails to resolve the issue, the disputes are referred to an arbitrator under the settler state's commercial arbitration legislation. The arbitrator's decision is binding on the parties, and the relevant provisions typically also stipulate that the arbitration process, and any proceedings in connection with it, will remain confidential. There is some indication that IBAs may also contain provisions that contemplate recourse to settler courts for 'interim judicial relief in the nature of an injunction or other equitable relief' pending arbitration (Pinehouse 
Agreement, 2012, art.7). However, the lack of transparency around the agreements means that scholarly understanding of the extent to which IBAs might reach arbitral tribunals, or mediation, is lacking (McLean 2019; Robertson, 2015). "The arbitration universe is...a closed world; it gives no voice to those parties who are external to the contractual order" (Perez, 2016:105).

Scholarship predicts that private parties may make use of formal contracts to structure their relationships even when they have no intention of using formal contract enforcement mechanisms (Hadfield and Bozovic, 2016). That is, parties in relational contracts may be content to rely on other tools like 'reputation' to induce compliance. Here, the central purpose of formal contracting then, is "to coordinate beliefs about what constitutes a breach of a highly ambiguous set of obligations" (Ibid: 982). Speaking of a 'highly ambiguous set of obligations', consider how negotiators are said to approach the question of the "no-protest" clauses. As one interviewee stated, "lawyers fight at length about this point", as they try to shape the precise contract language that will put into words exactly "how ...consent [is] rendered, and how can it be taken away". The negotiators I interviewed confirmed that companies will seek "life-of-theproject consent", "irrevocable consent", and "blank cheque consent" as well as "no-protest clauses" in which they attempt to "bind everyone" [in the community], and try to get the Band "to promise there will be no trouble...". More than one negotiator I interviewed stated that they advise Bands not to concede to these demands, with one explaining that "you can never bind the members, the youth, the hereditary leaders... If they decide to blockade the road, the leadership is at a loss - all they can do is not sanction it". Another interviewee admitted, however, that the First Nation is often forced to agree to terms that obligate the Chief and Council to take "positive steps to deter protestors or to make public statements denouncing their actions". 5

Beginning with the critical legal studies movement and continuing to today, scholars have demonstrated how the terms of contracts are almost always imposed by the stronger, better-resourced repeat players (Galanter, 1981; Macauley 2003; and see recently Cutler and Dietz, 2017). O'Faircheallaigh's research confirms that this dynamic is present with respect to IBAs as well: companies use their substantial experience negotiating with Indigenous peoples to gain advantageous contract terms (2016). But while size, power and experience matter in negotiations, as Affolder makes clear, there is also a "less visible and pernicious privileging that occurs through contractual norm-setting" (216).

A contract is supposed to be the "quintessential expression of a liberal theory of society" (Zumbansen 2018:3). It is meant to create a binding basis for a reciprocal exchange of commitments (Ibid.) That is, contract law's role has always been one of facilitating rather than putting conditions around what may be 'autonomously' agreed to (Affolder 2017:217). But as O'Faircheallaigh demonstrates by pointing to the widespread use of 'boilerplate' or template agreements, indications are that there really is very little bargaining going on: "The company determine[s] exactly what it [i]s prepared to agree to, enshrine[s] this in the template agreement, and move[s] from that position only when absolutely necessary" (2016: 168). Further as Affolder has argued, "Contract lawyers are well aware that it is in the boilerplate, in the creation of contractual norms, forms and defaults, that power gets divided and that winners and losers are made" (Affolder 2017, 215). Even more crucial in this context is the degree to which non-parties - state actors - seem to set the terms for the 'negotiation'. Consider the following case study based on a recent judicial review application challenging the issuance of an early exploration permit in Ontario's far north ${ }^{6}$ :

Eabametoong v Landore ...(and Ontario) 
Eabametoong First Nation (EFN) is a remote Anishinabe community situated in Treaty 9 territory. A junior mining company, Landore Resources, applied for an exploratory drilling permit in the area of two lakes that are used year-round by several Eabametoong families for sustenance, cultural, and spiritual purposes according to the applicable Indigenous stewardship laws governing family clans (Atlookan, 2016). Over a period of several years, the community leaders and company officials engaged in backand-forth communications about EFN's wish to strike a memorandum of understanding (MOU) to formalize the parties' expectations on the basis of good faith and respect, and their desire to meet in person with the company leadership to discuss affected clans' concerns. Officials in Ontario's Ministry of Northern Development and Mines (the Ministry) were involved at various stages, attempting to facilitate meetings, taking notes of community concerns and discussing them with the company. At one point, Ministry officials urged Landore to get in touch with EFN leaders, saying that the permit would not be issued until the community's concerns were met through the negotiation of an MOU (Applicant's factum at 7). The company presented EFN with a boilerplate agreement, but the community continued to press for various measures specific to their concerns. This exasperated the company, who stated that it had "successfully used this MOU template with [another Band]... and suggested to EFN to contact [their Chief]" if they needed further convincing (Landore's factum, 2016).

Later, when the issue took on a new urgency for Landore as they were negotiating to sell their assets to Barrick Gold, the Ministry and Landore had a private face-to-face meeting without informing Eabametoong leaders. Landore advised the Director that it needed the permit to be approved quickly. There is some evidence that the Ministry pressed the company to address some of the community's key demands at this meeting - including the decommissioning of the company's previous camp in the territory (Applicant's Factum at 7). Very soon after, the Ministry wrote to EFN informing the leaders that a decision would be made about the permit in a matter of days, and requesting any information the community wished to provide about adverse impacts. Eabametoong requested a meeting with Landore, who refused. EFN leaders subsequently wrote to the Ministry expressing concerns about both the project and the process. The Ministry responded with possible terms and conditions for permit approval and requested a swift response. EFN provided a letter from the community's lawyer setting out their objections in more detail, but the Ministry went ahead and issued the permit without replying to EFN.

On judicial review, the Court overturned the approval. It held that since the Crown had 'delegated' parts of its duty to Landore, the company's actions and the reasonable expectations they created by making promises to EFN were relevant to whether the duty to consult and accommodate was met. The Court stressed that the duty to consult does not give Eabametoong the right to unilaterally insist that a MOU be in place before the permit can be granted, or that any other process take place, but that because Landore had agreed to both the MOU and the community meeting, there was a responsibility to follow through, or at least offer Eabametoong an explanation. What the Court took issue with in this case was the sense that the purpose of the process switched from mutual understanding to facilitating approval in response to commercial timelines, holding that the Crown may not conclude a consultation process in consideration of external timing pressures when there are outstanding issues to be discussed.

What is most interesting in examining this case is that the Ministry took the position that EFN's insistence on an MOU was 'contrary to legal requirements and Ministry policy', but the Ministry did not communicate this to Eabametoong during the negotiations, instead seeming to attempt to facilitate negotiation towards an MOU itself. The policy in question is the Ministry's operational policy on 
"Consultation and arrangements with Aboriginal communities at early exploration" (MNDM, 2012). It states:

"Early exploration proponents and Aboriginal communities should not underestimate the importance of their role in the process. While MNDM's specific expectations are outlined in Part II of this Policy, early efforts to engage with one another, beyond the minimum processes required pursuant to the Mining Act and this Policy, will lead to more effective and timely results later. Building relationships and goodwill may lead to mutual commitments and arrangements and provide the certainty and stability for a project that permitting processes alone cannot achieve. Aboriginal communities and industry proponents must be willing to work constructively to understand one another's interests and perspectives and to find practical ways of addressing concerns and realizing opportunities that mineral exploration may have to offer" (at 2, my emphasis).

This amounts not only to a state endorsement of the 'opportunities' that mining presents for communities, but also an admission that contracting can lead to outcomes that permitting cannot provide. Later, the policy re-iterates that "proponents are strongly encouraged to make efforts to reach arrangements with communities in advance of submitting an application" and states that "arrangements that address concerns of Aboriginal communities related to consultation and mitigation will enable more timely decisionmaking by MNDM" (at 8). The Ministry further encourages proponents to support First Nations' capacity to engage in negotiations by directly re-imbursing their expenses or paying for technical services, and promises that "MNDM will support these contributions by ensuring they are eligible expenses for assessment credit under the Mining Act" (9). The MNDM states that proponents should strive to include various commitments in their "arrangements" with communities, such as seasonal modifications to work schedules or environmental monitoring, and states that should no agreement be possible, the Ministry may include such measures as conditions on the permit (9).

The MNDM even articulates specific content suggestions for the contracts, stating that the arrangements "should, ideally, reflect the following principles: be proportional to the nature, scale and duration of the project and its potential impacts; not place an excessive burden on the proponent or undermine the feasibility of the project; and be sufficiently transparent to satisfy MNDM's reporting requirements while also helping to manage expectations and bring a level of certainty and consistency to the field" (11). Finally, the province also funds a 'Community Consultation Liaison Officer', a member of the community's Band office whose job description is to support the community’s capacity to engage with the Ministry and industry regarding mineral exploration.

As Cutler (2018) argues, private capital will always seek to embed risks in the public domain - here, we can see that it is not so much the contract remedies themselves that determine the risk-sharing amongst the parties, but the structure of the public law regime. Because the duty to consult and accommodate lies formally on the state, companies are free to engage as they wish, exploring whether there are any gains to be made from contracting, but never with a down-side risk that it could affect their entitlements to the permit. It is the state that is ultimately on the hook when the First Nation and company parties fail to come to terms. And of the course the community - as in this case, if they had not launched the litigation, they would have been saddled with the negative effects of the new drilling, as well as the still-notdecommissioned prior work camp. 
What this case demonstrates is the high degree of penetration of state actors implementing public law processes, such as permitting for early exploration, into the negotiations towards ostensibly 'private' agreements. State actors deliberately delegate certain aspects of the 'consultation' to the compnaie, but they do not completely "check out" as one negotiator put it. This results in the situation in which First Nations find themselves engaging in discussions with the Crown in which they take hard-line positions so as to raise the bar of what might be expected of the company in their separate, 'private' negotiations towards an IBA. Ultimately, it is not only that the settler state law shapes the context and contours of what can be negotiated between the parties, it is almost to the point that the state actors effectively determine the terms, and then - as we saw in the Yahey case - the settler state seeks to draw inferences adverse to Indigenous land interests from the very fact of the deals. As relational contract theory would predict, the agreements themselves are embedded in a web of relations, with the structure of the web determined by the settler state's public law. The legal architecture into which any 'arrangements' may fit has been systematically structured by the settler state to favour the companies' access to Indigenous lands for extraction.

\section{Part III: Extraction Contracting: How 'Private' Agreements Serve the Settler State}

What is the precise role of the state in the negotiation of IBAs? There is by no means agreement in the literature as to how to characterize the role state governments are playing. Hall (2012) argues that governments are "not neutral arbitrators" in these circumstances; others have observed that industry and government seem to be aligning themselves; or that "government is relegated to an external observational role" (Caine and Krogman 2010 at 77). Fidler and Hitch (2009) say that the Crown 'underpins' the agreements (6). A Library of Parliament publication on IBAs from 2014 states that "[w]ith a few exceptions, governments are not directly involved in the development or negotiation of these bilateral arrangements" (Kielland, 2015). Similarly, Cameron and Levitan (2014) characterize the striking of the deals as a "privatization of the federal duty to consult Indigenous peoples about resource development" (25) and posit that "the longstanding interest of the state in promoting northern resource development is better achieved by not being directly and formally involved...except, importantly, at the level of upholding contract law" (27). The more recent evidence, I suggest, tends towards a much more active role for state actors in the contractual regime.

Although the use of IBAs remains formally 'elective' (however necessary it is on the ground), extraction contracting is woven into various public processes, not the least of which is permitting and approvals. To use the most obvious example, that of environmental assessment, IBAs often purport to bind parties to certain predetermined positions on the precise issues that are being adjudicated by public regulators. Further, if 'private law' is meant to denote arrangements between two private contracting parties, it is important to remember that IBAs are actually negotiated with Indigenous governing authorities, lending them a public character in addition to the fact that they are backed by the state enforcement of settler contract law and its specific remedies, or so we often assume. The state's regulatory proceedings also layer deadlines into the negotiating process, as do commercial imperatives (as was observed with Landore and EFN), which add pressure to already high-stakes situations. The formal legal authority of public officials is seen in stark contrast to the actual power and authority exercised by private actors, in relation to permitting as a classic case. Finally, there is continuing application of the settler law of injunctions, 
which further structures, in the state's interests, the 'remedies' available to the parties to an IBA (Ceric, this volume). The settler law of injunctions mobilizes the threat of state violence through police or military force to bolster the state's claims to exclusive territorial authority. It is clear that there is no way to conceive of these agreements as wholly private. The state is intimately involved -- arguably a party to the deal.

In this section, I argue that the phenomenon of "extraction contracting", even as it masquerades as a mode of private governance, in fact engages crucial public and constitutional governance questions. I conclude that it is not so much that the contracts are filling a gap in the inadequate public regulatory regime and associated jurisprudence (although the inadequacy is real), but that the public law regime is actively holding open the space for extraction contracting to fill because it insulates the settler law from demands for reform. If we take a clear look, based on these insights, we can see that the status quo flows from more-or-less deliberate decisions by state actors to rely on extraction contracting to determine the highly political outcomes to conflicts over land that are in the long-run detrimental to the Indigenous parties. This is a struggle for the control of lands and resources, and the settler state is invested in delaying the inevitable break-down of its jurisdictional authority on those lands, which will entail major wealth redistribution from capital to Indigenous peoples.

\section{lex extractionis}

Many of the questions driving my inquiries here are common to the contemporary scholarly literature on transnational private governance, such as: What are the mechanisms through which private authority gains legitimacy? And, "[h]ow have specific private modes of governance gained standing as (de facto) public authority"? (Hartmann and Kjaer 2018: 4). Extraction in Canada is obviously shaped by dynamics beyond state borders, and the literature on transnational law -- attentive as it is to legal pluralism and nonstate actors -- is instructive even as I believe there is a sui generis character to the way that consent by contract has emerged in Canada.

Perhaps IBAs are doing just what they are intended to do: a contract is a "device ... for the separation of social relations from state law" (Collins, 1999: 123). But why, how, and who does it benefit? IBAs are certainly not unique - there is a semi-political or constitutional character to other types of major contractual regimes as well (Perez, 2016). A central preoccupation of scholars of transnational private governance is the question of what justifies the exemption of these transactions, essentially constitutional in character, from public law's grasp? The roots of a "sharp distinction between the private and public orders", according to Perez (2016), lies within the lex mercatoria, a body of accepted trading principles used by merchants across early trading routes. "The purpose of the lex mercatoria was understood, historically, as protecting business expectations; the primary task of the lex mercatoria was to render business relations more calculable" (96). Here, in extraction contracting, we can discern a similar business purpose, but we also observe the way that 'lex extractionis' (if I may) imposes the costs of contested projects onto what these scholars might call the "extra-contractual community". Extraction encroaches deeply into the social and ecological relations on the territories on which it takes place: "[t]his embeddedness is highly incongruent with the image of an isolated 'business relation' (Perez 2016: 98).

Claire Cutler, describing the public/private distinction, argues that it is fundamental to liberal theory to ensure that the public realm "constitutes a contested political space subject to regulation by legitimate political authorities" in contrast to the private sphere which is "understood to be an apolitical realm of 
individual freedom and autonomy, outside the scope of legitimate political regulation" and primarily dealing with economic activity between rational actors of equal bargaining power (2018: 70). The task of separating public from private, she argues, rests on differentiating economics from politics, which is

an analytical distinction that has little empirical validity. The separation of the political and the economic is an analytical and ideological separation engendered by the capitalist mode of production that functions to depoliticize the fundamentally distributional and political nature of economic activity. This separation masks the underlying structural connection between the two spheres and the power imbalances that inhere in capitalist economic and social relations (71).

Further, and most pertinent here, is Cutler's assertion that "the assumption of the apolitical nature of private/economic exchanges ignores the more generalized and public implications of these exchanges. In essence, the analytical distinction does not bear out in the lived experiences of people who are impacted by private agreements" (71). In the case of IBAs, it is plainly obvious that many interests are engaged in the periphery of these contracts that are conspicuously left out of the deal. These include the interests of a broader public in environmental sustainability, climate stability, biodiversity protection, conservation of intact ecosystems; the pressing questions of Indigenous governing authority, inherent jurisdiction and the overall impact of projects on Treaty rights, not just those of the contracting parties but neighboring nations. Something else traded away seems to be the leverage of the communities when they bargain collectively, including the ability to secure strategic, regional and long-term interests and visions emerging from their own Indigenous social, political and legal orders. Thus, while the dynamics around IBAs may share features with those surrounding other types of commercial contracts, the substance of what is being traded here is crucial. As Affolder (2017) demonstrates in another context, the legal form may resemble a commercial contract, but the "subject-matter implicates issues that commercial contract law cannot resolve" (221): rights to land, inherent jurisdiction, sovereignty, the authority to decide.

Norms are shifted through struggle. How can this regime be transformed? Because IBAs are confidential and their contents closely guarded, even considered 'proprietary' by the firms that negotiate them (O'Faircheillaigh, 2016), it is not possible to easily advocate to turn the agreements into public policy instruments applicable more broadly throughout a region, although the case has been made that this is required (McLean, 2019). It is true that it is not only the companies that want confidentiality, First Nations are said to seek and value the confidentiality clauses as well - mostly out of concern about state clawback of what is called "own-source-revenue", again drawing into the picture the larger structural conditions of settler colonial capitalism. But the secrecy leads to distrust and "toxicity within the communities", according to one interviewee, while the benefits of confidentiality largely adhere to companies. The lack of transparency also prevents comparison between the magnitude of funds paid to First Nations versus the amounts received in state subsidies to the extractive industry, another area that could benefit from less secrecy.

While it may be true that, as Gilmour and Mellett (2013) argue, "the regulator cannot offer to a First Nation the kinds of benefits that can be achieved in an IBA", neither can the regulatory process, as it is currently structured under settler law, provide an avenue for a First Nation to offer a definitive 'no' to a project that the community does not ultimately consent to. That is, the contractual regime offers no path towards self-determination in terms of territorial governing authority or proprietary rights to lands and 
resources. Indigenous peoples need space to envision and pursue development that "responds to the depth of Indigenous territorial responsibilities" (McCreary and Turner, 2018: 26)

Consent by contract is a regime that erodes, over time, the territorial rights and sovereignty of Indigenous peoples, and IBAs in particular contribute to the undermining of resistance, criminalization of protest and division within and between Indigenous communities (Veltmeyer and Bowles 2014). Without recourse to this weak justification that IndigeFnous peoples are participating, benefitting or 'sharing in the wealth that comes from their territories', we would much quicker demand the breakdown of the entire edifice. But as Cutler argues, the mix of public versus private authorities in complex governance questions is "not fixed, but mutable, and open in places to resistance" (2018: 16). While the contractual regime may, for now, be insulating the state from more radical and fundamental challenges to its territorial authority because IBAs provide a thin cover of consent for the contested projects, this is also vulnerable to changing norms and practices.

\section{Conclusions}

I have argued here, drawing on Cutler and Dietz's (2019) framing in the context of private transnational governance, that 'consent by contract' is a mode of governance that attempts to define the social, political, ecological and economic relations regarding the use of Indigenous lands solely through confidential bargaining and agreement-making between private extraction companies and First Nations, but in fact affords the state a key role in setting the terms. But 'consent' must require something more than this. As Szablowski says, "consent processes are clearly political events that mobilize affected community members in a collective experience of active decision making about the future. They take place in public spaces. As a result, they are more likely to galvanize attention, and generate discussion and deliberation within a group" (2010: 119). What Indigenous peoples are seeking is not a better contractual regime; it is "a new constitutional order" (Szablowski 2010: 114).

Scholars have begun to explore whether the 'triumphant rise of contract' (Zumbansen 2018:1) can be harnessed for creative, transformational change or what some of them term "radical transactionalism" (Morgan and Kuch, 2015; Crowder, 2016). Odumosu-Ayanu (2014) has proposed a move to tripartite contractual agreements, or "multi-actor contracts", between investors (mining companies), local communities and 'host states' as a way of addressing many of the dilemmas explored here. Gaathi and Odumosu-Ayanu (2015) argue that new contractual regimes demonstrate "real potential to address or mitigate the absence of remedial and responsibility regimes for the adverse impacts of extractive industry activities on individuals and communities" (69). While reforms such as these could certainly mitigate some of the worst aspects of the contractual turn, specifically the lack of remedies for affected "nonparties", this analysis has shown that it is in fact the public law regime -- the settler law and jurisprudence -- that presents the biggest barriers to restoring Indigenous control of lands.

Contract law itself changes slowly, through a dynamic process of mutual adjustment of expectations. The public law framework, it is hoped, could change quicker. Some scholars believe that the settler courts may (and must) provide openings and new interpretations that could shift the balance of power (see for example, Kamphuis, 2017). Others believe political tides may be shifting in favour of Indigenous peoples, which could usher in a new legislative framework for extraction. But in Canada, these hopes have been repeatedly dashed. This is because, as Julie Tomiak has argued, the settler state "is no less committed to the elimination and displacement of Indigenous peoples and sovereignty than more overtly genocidal 
colonial state practices of the past", but simply employs new strategies, a central one of which is "an increased reliance on...contractual relations" (2016: 222).

The settler state continues to be heavily invested in the profitability of the extractive sector. And yet, it is clear that the environmental and social costs of extractivism for the communities and territories in question far exceed the benefits that can be gained through extraction contracting. Further, since the 'new extractive frontiers' are frequently areas of high biodiversity and support a variety of critical ecological functions (Gedicks 2015), there are broader, diffuse costs borne by a wide range of interests - effects on water and air quality, climate instability, biodiversity loss, fragmentation of intact ecosystems, amongst others, that are completely uncompensated. Meanwhile the 'benefits' from the extraction are highly concentrated - -they accrue to a small number of companies and their investors-- even governments do not derive much in the way of revenues from mining (Veltmeyer and Bowles, 2014), especially for remote mines (Kuyek, 2019).

As Edward Cohen (2019) contends, contractual regimes are "centers of contestation over the boundaries between public and private power and authority"; they constitute "crucial arenas in which patterns of power and purpose are constructed". But as I have argued here, while the contractual form, construed as a matter of private law, is a critical "vector of power" (Cutler and Dietz, 2019), the settler state must be considered a party to the deal-making. Consent by contract is a technique of the contemporary settler state to normalize its own tenuous authority over lands and resources in the face of increasingly convincing counter-claims. There are always spaces for resistance, however, and the contractual regime with its bare veneer of 'consent', is coming under increasing pressure from Indigenous land defenders: "the perpetual threat of Indigenous nations is that they are a reminder of the settler's own precarious claims to land and belonging" (Estes, 2018: 248).

\section{References}

Acuña, R. M. (2015). The politics of extractive governance: Indigenous peoples and socio-environmental conflicts. Extractive Industries and Society, 2(1), 85-92.

Natasha A Affolder, 'Rethinking Environmental Contracting' (2010) 21 Journal of Environmental Law and Practice 155.

Natasha Affolder, 'Transnational Conservation Contracts' (2012) 25 Leiden Journal of International Law 443.

Affolder, N. (2017). Transnational Carbon Contracting: Why Law's Invisibility Matters. In The Politics of Private Transnational Governance by Contract (1st ed., pp. 215-236). London: Routledge.

Burrows, A. S. (2012). The Law of Restitution (3rd ed.). Oxford: Oxford University Press.

Caine, K. J., \& Krogman, N. (2010). Powerful or Just Plain Power-Full? A Power Analysis of Impact and Benefit Agreements in Canada's North. Organization \& Environment, 23(1), 76-98.

doi:10.1177/1086026609358969 
Cameron, E., \& Levitan, T. (2014). Impact and Benefit Agreements and the Neoliberalization of Resource Governance and Indigenous-State Relations in Northern Canada. Studies in Political Economy, 93(1), 2552. doi:10.1080/19187033.2014.11674963

Dezalay, Y. 1994. "The forum should fit the fuss: the economics and politics of negotiated justice" in M Cain and C Harrington (eds), Lawyers in a Post-Modern World (Buckingham: Open University Press) 124-154.

Fidler, C. (2010). Increasing the sustainability of a resource development: Aboriginal engagement and negotiated agreements. Environment, Development and Sustainability, 12(2), 233-244.

doi:10.1007/s10668-009-9191-6

Fidler, C., \& Hitch, M. (2007). Impact and Benefit Agreements: A Contentious Issue for Environmental and Aboriginal Justice. Environments: A Journal of Interdisciplinary Studies, 35(2), 49.

Fidler, C., \& Hitch, M. (2009) "Used and Abused: Negotiated Agreements". Submission to Rethinking Extractive Industry: Regulation, Dispossession and Emerging Claims Conference, York University, Toronto.

Galanter, Marc. (1981) Justice in many rooms: courts, private orderings and indigenous law', Journal of Legal Pluralism 19(1) 1-48.

Gibson, G., \& O'Faircheallaigh, C. (2010). IBA Community Toolkit: Negotiation and Implementation of Impact and Benefit Agreements. Retrieved from http://www.ibacommunitytoolkit.ca/pdf/IBA_toolkit_March_2010_Section_1.pdf

Gilmour, B., \& Mellett, B. (2013). The Role of Impact and Benefits Agreements in the Resolution of Project Issues with First Nations. Alberta Law Review, 51(2), 385. doi:10.29173/alr71

Gogal, S., Riegert, R., \& Jamieson, J. (2005). Aboriginal Impact and Benefit Agreements: Practical Considerations. Alberta Law Review, 43(1), 129.

Graben S., A. Cameron and S. Morales (2019) Gender Impact Analysis of Impact Benefit Agreements: Representation Clauses and UNDRIP. Available on SSRN.

Imai, S. (2017). Consult, Consent \& Veto: International Norms and Canadian Treaties. In The Right Relationship, Reimagining the Implementation of Historical Treaties (1st ed., pp. 370-409). Toronto: University of Toronto Press.

Kamphuis, Charis. "Litigating Indigenous Dispossession in the Global Economy: Law's Promises and Pitfalls" (2017)14:1 Brazilian Journal of International Law 165-225.

Karassin, O., \& Perez, O. (2018). Shifting between Public and Private: The Reconfiguration of Global Environmental Regulation. Indiana Journal of Global Legal Studies, 25(1), 97-129.

doi:10.2139/ssrn.3120497

Kennedy, D. (2001). The Political Stakes in "Merely Technical” Issues of Contract Law. European Review of Private Law, 10(1), 7-28. 
Kielland, Norah. (2015) "Supporting Aboriginal Participation in Resource Development: The Roel of Impact and Benefit Agreements" Library of Parliament, Canada, https://lop.parl.ca/staticfiles/PublicWebsite/Home/ResearchPublications/InBriefs/PDF/2015-29-e.pdf

Macaulay, S. (1977). Elegant Models, Empirical Pictures, and the Complexities of Contract. Law \& Society Review, 11(3), 507. doi:10.2307/3053130

Macaulay, S. (2003). The Real and the Paper Deal: Empirical Pictures of Relationships, Complexity and the Urge for Transparent Simple Rules. The Modern Law Review, 66(1), 44-79.

doi:10.5040/9781472559449.ch-003

Macdonald, F. (2011). Indigenous Peoples and Neoliberal "Privatization" in Canada: Opportunities, Cautions and Constraints. Canadian Journal of Political Science, 44(2), 257-273.

doi:10.1017/s000842391100014x

Macneil, I.R. (1962). Power of Contract and Agreed Remedies. Cornell Law Review, 47(4), 495-528. http://scholarship.law.cornell.edu/clr/vol47/iss4/1

Mills, S.E., \& Sweeney, B. (2013). Employment Relations in the Neo-Staples Resource Economy: IBAs and Aboriginal Governance in Canada's Nickel Mining Industry. Studies in Political Economy, 91(1), 733.

Morgan B; Kuch D, 2015, 'Radical Transactionalism: Legal Consciousness, Diverse Economies, and the Sharing Economy', Journal of Law and Society, vol. 42, pp. 556 - 587, http://dx.doi.org/10.1111/j.14676478.2015.00725.x

Natural Resources Canada, Earth Sciences Sector, \& Canada Centre for Mapping and Earth Observation. (2018, February 08). Indigenous Mining Agreements. Retrieved July 15, 2019, from https://atlas.gc.ca/imaema/en/

Odumosu-Ayanu, Ibironke. 'Multi-Actor Contracts, Competing Goals and Regulation of Foreign Investment' (2014) 65 University of New Brunswick Law Journal 269.

O'Faircheallaigh, C. (2004). Evaluating agreements between indigenous peoples and resource developers. In Honour among nations? Treaties and agreements with indigenous peoples (1st ed., pp. 303-328). Melbourne: Melbourne University Press.

O'Faircheallaigh, C. (2010). Public participation and environmental impact assessment: Purposes, implications, and lessons for public policy making. Environmental Impact Assessment Review, 30(1), 1927. doi:10.1016/j.eiar.2009.05.001

O'Faircheallaigh, C. (2013). Extractive industries and Indigenous peoples: A changing dynamic? Journal of Rural Studies, 30, 20-30. doi:10.1016/j.jrurstud.2012.11.003

O'Faircheallaigh, C. (2016). Negotiations in the Indigenous world. Aboriginal Peoples and the Extractive Industry in Australia and Canada (1st ed.). New York and London: Routledge. 
Olynyk, J., Bergner, K. B., \& Shipley, L. (2018, September 21). The Impact of Disclosure of Private Impact Benefit Agreements. Retrieved July 15, 2019, from https://www.lexpert.ca/article/the-impact-ofdisclosure-of-private-impact-benefit-agreements/

Owen, J. R., \& Kemp, D. (2013). Social licence and mining: A critical perspective. Extractive Relations: Countervailing Power and the Global Mining Industry, 38(1), 29-35.

doi:10.9774/gleaf.9781783534784_4

Papillon, M., \& Rodon, T. (2016, December). Environmental Assessment Processes and the Implementation of Indigenous Peoples Free, Prior and Informed Consent. Retrieved July 15, 2019, from https://www.chairedeveloppementnord.ulaval.ca/sites/chairedeveloppementnord.ulaval.ca/files/environme ntal_assessment_processes_and_the_implementation_of_indigenous_peoples_fpic.pdf

Prno, J., Bradshaw, B., \& Lapierre, D. (2010). Impact and Benefit Agreements: Are they working? Retrieved July 15, 2019, from https://pdfs.semanticscholar.org/87c4/f66ec25ee1bd3caedeea8d92002e42525f35.pdf?_ga=2.66606509.20 30830348.1563222688-1496975773.1558028986

Saugeen First Nation v. Ontario (Minister of Natural Resources and Forestry), 2017 ONSC 3456, 4 CNLR 213 at para 8.

Sosa, I., \& Keenan, K. (October 2001). Impact benefit agreements between aboriginal communities and mining companies: their use in Canada. Retrieved from https://www.cela.ca/sites/cela.ca/files/uploads/IBAeng.pdf

St-Laurent, G. P., \& Billon, P. L. (2015). Staking claims and shaking hands: Impact and benefit agreements as a technology of government in the mining sector. The Extractive Industries and Society, 2(3), 590-602. doi:10.1016/j.exis.2015.06.001

Stanley, A. (2016). Resilient Settler Colonialism: "Responsible Resource Development," "FlowThrough" Financing, and the Risk Management of Indigenous Sovereignty in Canada. SAGE Journal, 48(12), 2422-2442. https://doi.org/10.1177/0308518X16660352

Szablowski (2007) Transnational Law and Local Struggles: Mining, Communities and the World Bank. Oxford \& Portland: Hart Publishing, 2007.

Szablowski, D. (2010). Operationalizing Free, Prior, and Informed Consent in the Extractive Industry Sector? Examining the Challenges of a Negotiated Model of Justice. Canadian Journal of Development Studies / Revue Canadienne Détudes Du Développement, 30(1), 111-130. doi:10.1080/02255189.2010.9669284

Thel, S., \& Siegelman, P. (2010). You DO Have to Keep Your Promises: A Disgorgement Theory of Contract Remedies. Willim \& Mary Law Review, 52, 1181. doi:10.2139/ssrn.1353402

Tomiak, Julie (2016). "Navigating the contradictions of the shadow state: the Assembly of First Nations, state funding, and scales of indigenous resistance. 97:3 Studies in Political Economy 217-233.

Tsleil-Waututh Nation v. Canada (Attorney General), 2018 CAF 153, 2018 FCA 153. 
Weitzner, V. “'Dealing Full Force”: Lutsel K'e Dene First Nation's Experience Negotiating with Mining Companies' (Case Study, The North-South Institute and Lutsel K'e Dene First Nation, 4 January 2006) 30 .

Zumbansen, P. (2019). Liberalism's Global Mirror? Worldwide Contracting and 'No Alternative'? IN A.Claire Cutler \& Thomas Dietz (eds.), The Politics of Private Transnational Governance by Contract.

Understanding Successful Approaches to Free, Prior, and Informed Consent in Canada. Part 1. (2015, September). Retrieved July 15, 2019, from

https://www.resolve.ngo/docs/blc_fpic_successes_report_1636888541680231649.pdf

\footnotetext{
${ }^{1}$ The interviewees were granted anonymity in order to protect client relations, and the interview protocol was crafted to avoid discussion of specific negotiations or outcomes and to focus instead on broad trends and dynamics. Individuals interviewed were Associates or Partners with major firms including the Firelight Group, Mandell Pinder, OKT Law, Ratcliff and Co. and Willms and Shier.

${ }^{2}$ EFN v Landore, and associated affidavits; Yahey v BC and associated affidavits; "freedom of information" requests filed with the Ontario Ministry of Energy, Northern Development and Mines in 2018 and 2019. Records requested included 'agreements and arrangements' reported by mining companies in 'Aboriginal Consultation Reports' filed under the Exploration Plans and Exploration Permits regulation of the Mining Act, O. Reg. 308/12, section 14, since 2012 and 'records of decision' and associated early exploration permits granted under the Mining Act in Ontario since 2012.

${ }^{3}$ Yahey v. British Columbia, 2015 BCSC 1302 (CanLii) at para 2.

${ }^{4}$ Interview A, April 30, 2019.

${ }^{5}$ Interview B, July 24, 2019.

${ }^{6}$ Eabametoong First Nation v Minister of Northern Development and Mines, Director of Exploration for the Ministry of Northern Development and Mines, and Landore Resources Canada Inc. (2018, Ont Div Ct)
} 